\title{
Study of Ring-Opening Reaction of Spiro[5.2]octenes with Aqueous Hydrohalic Acid: Substituent Effect on the Regioselectivity
}

\author{
Yuuki Nagamoto, Yoshiji Takemoto, ${ }^{*}$ Kiyosei Takasu* \\ Graduate School of Pharmaceutical Sciences, Kyoto University, Yoshida, Sakyo-ku, Kyoto 606-8501, Japan \\ Fax +81(75)7534604; E-mail: kay-t@pharm.kyoto-u.ac.jp \\ Received: 16.10.2012; Accepted after revision: 12.11.2012
}

\begin{abstract}
We describe here the regioselective ring-opening reaction of spiro[5.2] octenes with hydrohalic acids. It was observed that the electronic nature of a substituent on the cyclopropane ring would control the regioselectivity.
\end{abstract}

Key words: alkenylcyclopropanes, electrophilic addition, regioselectivity, ring opening, spiro compound

Cyclopropane framework is an attractive organic motif in terms of its biological property as well as its unique chemical reactivity. The relief of the high ring-strain energy, which provides a potent enthalpic driving force, facilitates a variety of unique chemical transformations. ${ }^{1}$ Cyclopropane compounds are found as naturally occurring substances $^{2}$ such as illudins, ${ }^{2 b, 3}$ duocarmycins, ${ }^{2 b, 4}$ and their related compounds, which display potent antitumor activity (Scheme 1). The bioorganic studies of these natural products proved that the ring-opening reaction of the cyclopropane ring induced by a nucleophilic attack of nucleobases or proteins is a key event. ${ }^{5,6}$ The mechanism of biological action of illudins is illustrated in Scheme 1.5a Michael addition by a thiol nucleophile of a protein, such as glutathione reductase (GSH), under acidic conditions ( $\mathrm{pH} \sim 6)$ gives active intermediate $\mathbf{A}$. The electrophilic intermediate A smoothly reacts with an appropriate nucleobase. As the result, aromatic bioconjugate $\mathbf{B}$ is produced by concurrent ring opening of the cyclopropane moiety by the $\mathrm{S}_{\mathrm{N}} 2^{\prime}$-type reaction.

Based on the mechanism, extensive efforts have been devoted to designing the illudin and duocarmycin analogues and to understanding their biological properties. ${ }^{6-8}$ Barone and co-workers examined the ring-opening reaction of duocarmycin SA derivatives, whose spirocyclopropane ring is electrophilically activated by the conjugation with a carbonyl group. ${ }^{9}$ They made clear that a nucleophile attacks preferably at the least substituted carbon atom of the cyclopropane ring. Moreover, the computational studies revealed that both the electronic and the steric effects of the substituent can influence the reactivity of the ringopening reaction. ${ }^{9 \mathrm{~b}}$ Thus, they concluded that the substituent effect would be helpful in exploring the chemical transformations of duocarmycin SA as well as in designing new analogues.

SYNLETT 2013, 24, 0120-0124

Advanced online publication: 10.12.2012

DOI: 10.1055/s-0032-1317745; Art ID: ST-2012-U0893-L

(C) Georg Thieme Verlag Stuttgart $\cdot$ New York

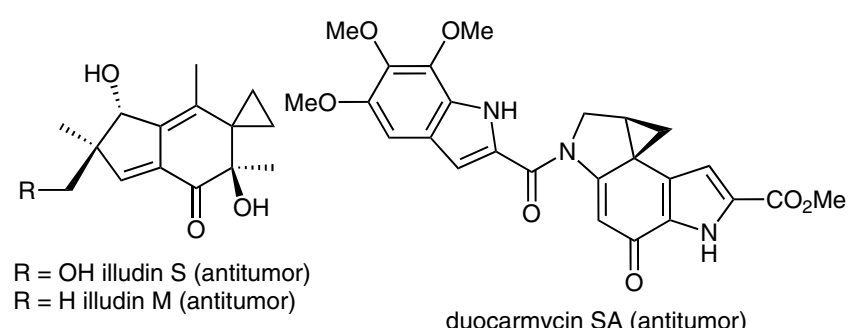

$\mathrm{R}=\mathrm{H}$ illudin $\mathrm{M}$ (antitumor)

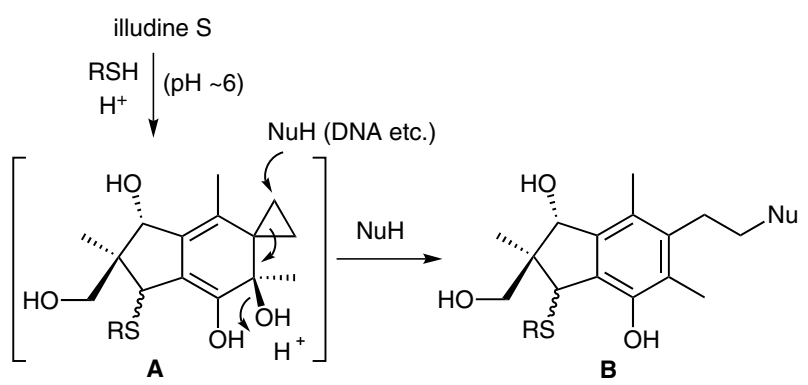

Scheme 1 Natural cancerostatic products containing a spirocyclopropane framework and the proposed biological action mechanism of illudins

Recently, we reported the synthesis of spirocyclic alkenylcyclopropanes $\mathbf{1}$, bearing a substituent on the cyclopropane ring, from fused cyclobutanols. ${ }^{10}$ The spirocyclic core of $\mathbf{1}$ is structurally related to illudins. Our intention is to design a new antitumor DNA-alkylating agent by using our synthetic reaction. For this purpose, the ring-opening reaction of alkenylcyclopropane $\mathbf{1}$, whose cyclopropane is not conjugated with an electron-withdrawing group, must be examined under aqueous conditions. Additionally, investigation of the regioselectivity would be an important issue because the cationic intermediate $\mathbf{C}$ has three different reactive sites with a nucleophile $\mathrm{X}^{-}$(Scheme 2$)$. When nucleophilic $\left(\mathrm{X}^{-}\right)$attack occurs at the substituted or nonsubstituted cyclopropane carbon atoms, 1,5-adducts 2 or $\mathbf{3}$, respectively, will be obtained via a conjugate addition (modes a and $\mathrm{b}$ ). On the other hand, direct addition of $\mathrm{X}^{-}$ at the tertiary cationic carbon of $\mathbf{C}$ will give 1,2-adduct $\mathbf{4}$ (mode c). Although a number of transition-metal-catalyzed ring-opening reactions of alkenylcyclopropanes were reported, , 111 to the best of our knowledge, only limited investigations for acid-mediated ring-opening reactions of inactivated alkenylcyclopropanes can be found in the literature. ${ }^{10,12}$ Moreover, the regioselective issues are unexplored. Herein, we describe the regioselectivity in the ring-cleavage reaction of spiro[5.2]octenes 1 with various aqueous hydrohalic acids (HX). 


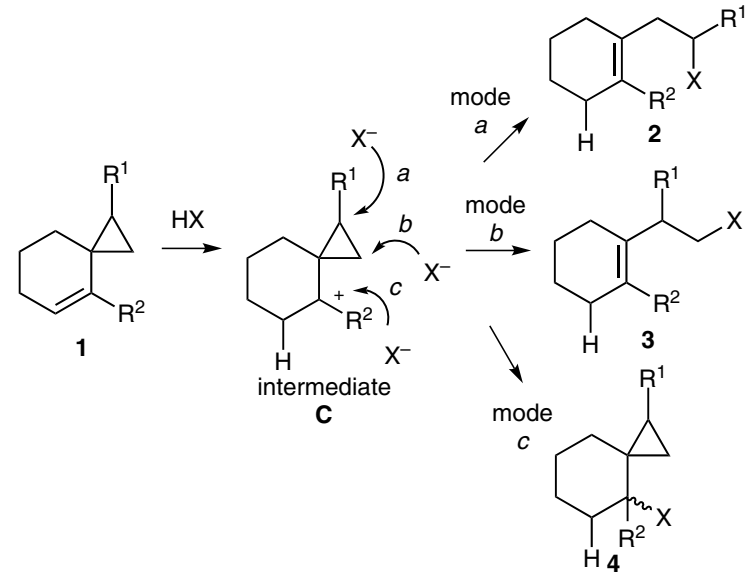

Scheme 2 Possible regioisomeric adducts 2-4 in the reaction of 1 with HX

At the outset of our study, ring-opening reaction of $1 \mathbf{a}^{9}$ bearing an alkyl substituent under aqueous acidic conditions was examined (Table 1). When 1a was treated with aqueous hydroiodic acid (HI), which was prepared in situ from TMSCl, NaI, and $\mathrm{H}_{2} \mathrm{O}$ (2 equiv each) ${ }^{13}$ in acetonitrile at ambient temperature, ring-opening reaction proceeded smoothly giving $\mathbf{2 a a}$ in $68 \%$ (Table 1 , entry 1 ). Namely, the product 2 aa was formed through the nucleophilic substitution at the more substituted carbon of $\mathbf{1 a}$ (mode a in Scheme 2). No isomeric adduct such as 3aa, which will be produced by the $\mathrm{C}-\mathrm{X}$ bond formation at the less substituted carbon (mode b in Scheme 2), was observed. As is the case in HI, secondary alkylbromide $\mathbf{2 a b}$ was obtained as a single isomeric product in the reaction of $1 \mathbf{a}$ with aqueous hydrobromic acid ( $\mathrm{HBr}$, Table 1, entry 2 ). The same regioselectivity as in acetonitrile was also observed in dichloromethane, although the chemical yield was decreased (Table 1, entry 3 ). With hydrochloric acid $(\mathrm{HCl})$, only electrophilic addition of $\mathrm{Cl}^{-}$to the substituted carbon occurred to afford 2 ac in $86 \%$ yield (Table 1, entry 4). It was found that, in the ring-opening reaction of $\mathbf{1 a}$ with $\mathrm{HX}$, a nucleophile attacks regioselectively at the more substituted carbon regardless of the nature of the nucleophiles.

The regioselectivity of the ring-opening reaction can be explained as shown in Scheme 3. After protonation of the alkene moiety of $\mathbf{1}$, the corresponding tertiary cation intermediate $\mathbf{C}$ is generated. Major product $\mathbf{2}$ should be obtained via nucleophilic attack of $\mathrm{X}^{-}$at the more substituted carbon [transition-state structure (TS) D], and minor product 3 via nucleophilic attack at the less substituted carbon (TS E). Partial positive charge $\left(\delta^{+}\right)$is delocalized at the tertiary or secondary carbon in $\mathbf{D}$ or $\mathbf{E}$, respectively. ${ }^{14}$ In the reactions of alkyl-substituted substrate 1a, TS D would be more stable than TS E owing to the cationic stability (primary vs. secondary carbocation), resulting in product $\mathbf{2 a}$ with high regioselectivity.

Next the reactions of $\mathbf{1 b}$ bearing an ether substituent with HX were carried out (Table 2). When $\mathbf{1 b}$ was treated with
Table 1 Reaction of 1a Having an Alkyl Side Chain with Various $\mathrm{HX}^{\mathrm{a}}$

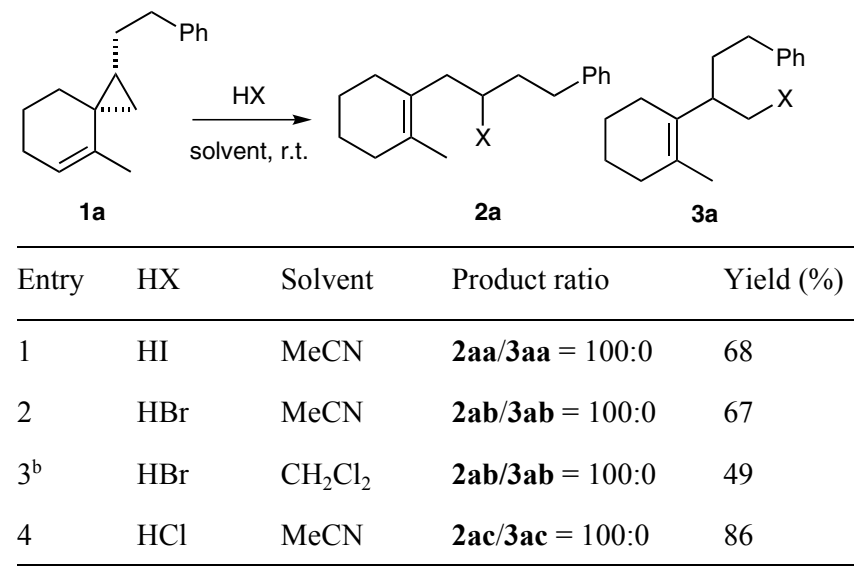

${ }^{a}$ Conditions: 1a $(0.1 \mathrm{mmol}), \mathrm{HX}$ (1.5 or 2.0 equiv), $\mathrm{MeCN}(0.2 \mathrm{M})$, r.t., $1-3 \mathrm{~h}$.

${ }^{\mathrm{b}}$ Compound 1a was recovered in $12 \%$ yield.

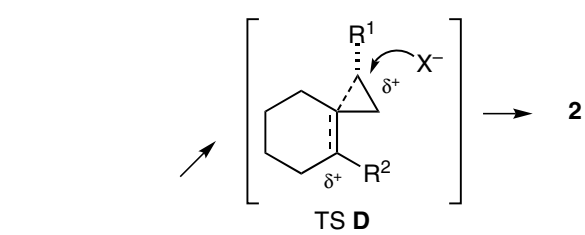

intermediate

C

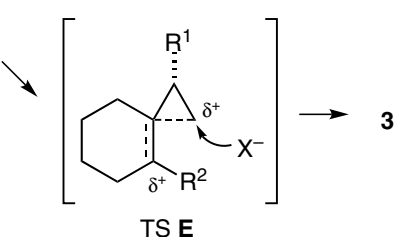

Scheme 3 Plausible mechanism of regioselectivity

HI, formation of primary alkyl iodide $\mathbf{3 b a}$ was observed as a minor product along with secondary alkyl iodide $\mathbf{2} \mathbf{b a}$ (Table 2, entry 1). In the reaction of $\mathbf{1 b}$ with $\mathrm{HBr}$ and $\mathrm{HCl}$, the mixture of $\mathbf{2 b}$ and $\mathbf{3 b}$ were also obtained, respectively (Table 2, entries 2 and 3). We guessed that an inductive effect would rationalize the formation of $\mathbf{3 b} .{ }^{15}$ Namely, the partially delocalized positive charge at the substituted carbon in TS $\mathbf{D}$ from $\mathbf{2 b}$ would be somewhat destabilized by the ether moiety (negative inductive effect). As the result, the regioisomeric ring-opening reaction via TS $\mathbf{E}$ giving 3b also proceeds as a minor path.

In order to make clear the negative inductive effect by the side chain on the cyclopropane ring, we investigated the reaction of 1c having an electron-withdrawing ester substituent (Table 3 ). Treatment of $\mathbf{1 c}$ with $\mathrm{HI}$ in acetonitrile afforded no $2 \mathbf{c a}$ but primary alkyl iodide $3 \mathbf{c a}$ in $75 \%$ yield (Table 3 , entry 1). The regioselectivity decreased when the reaction of 1c was carried out in the less polar solvents (Table 3, entries 2 and 3). The solvent effect supports that the regioselectivity of the ring-opening reaction is dependent on the electronic factor of the intermediate or transition state. When the reaction of 1c was carried out with $\mathrm{HBr}$, primary alkyl bromide $\mathbf{3} \mathbf{c b}$ was obtained along with 
Table 2 Reaction of $\mathbf{1 b}$ Having a Benzyloxymethyl Substituent with Various $\mathrm{HX}^{\mathrm{a}}$

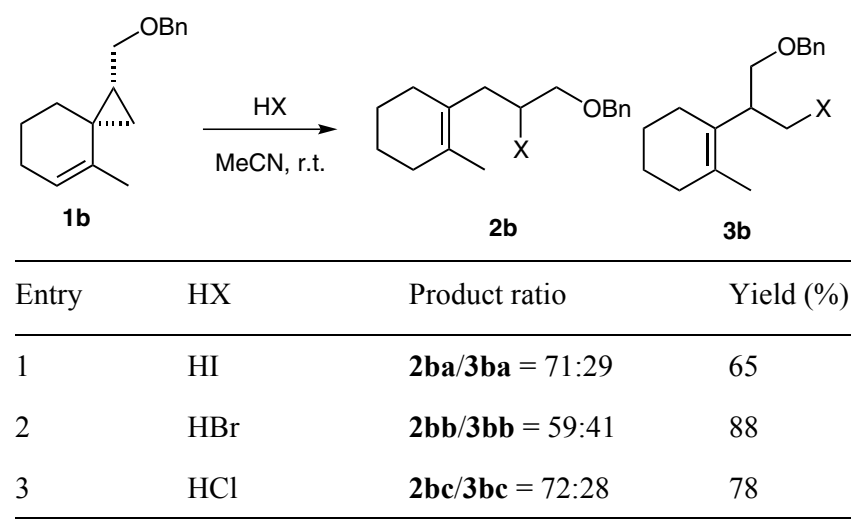

${ }^{\text {a }}$ Conditions: $1 \mathrm{~b}(0.1 \mathrm{mmol}), \mathrm{HX}$ ( 1.5 or 2.0 equiv), $\mathrm{MeCN}(0.2 \mathrm{M})$, r.t., $0.5-3 \mathrm{~h}$.

regioisomeric adduct $\mathbf{2 c b}$ (Table 3, entry 4). The observation indicates that the regioselectivity would be also dependent on the nature of the nucleophile $\left(\mathrm{X}^{-}\right)$. The reaction with $\mathrm{HCl}$ gave considerably complicated results (Table 3 , entries 5 and 6). At ambient temperature, ring-opening adducts 2cc and 3cc were obtained in 25\% yield with 33:67 diastereomeric ratio. As a major product, cyclopropylcarbinol 4cd was obtained in 32\% yield as a 1:1 diastereomeric mixture. Formation of $\mathbf{4 c d}$ resulted in 1,2-addition (mode $\mathrm{c}$ in Scheme 1) of water. As minor products, alcohols $2 \mathrm{~cd}\left(\mathrm{R}=\mathrm{CH}_{2} \mathrm{OBz}, \mathrm{X}=\mathrm{OH}\right)$ and $\mathbf{2 c d}(\mathrm{R}=\mathrm{OH}, \mathrm{X}=$ $\mathrm{CH}_{2} \mathrm{OBz}$ ) were also isolated in $8 \%$ and $2 \%$ yield, respectively. When the reaction was carried out at $80^{\circ} \mathrm{C}$, no $1,2-$ adduct 4 was detected but ring-opening products $2 \mathbf{c c}, 3 \mathbf{3 c}$, $\mathbf{2 c d}$, and $\mathbf{2 c d}$ ' were produced. It indicates that $\mathbf{4 c d}$ is a kinetic product, and $\mathbf{4 c d}$ is transformed into conjugated adducts at higher temperature.

The regioselective formation of $\mathbf{3} \mathbf{c a}$ from ester $\mathbf{1} \mathbf{c}$ strongly supports that the negative inductive effect of the substituent would control the position of the ring cleavage. Namely, the delocalized cation in the TS D (Scheme 3) would be delocalized by the negative inductive effect of the alkoxycarbonyl substituent. As the result, the ring-opening reaction preferably proceeds via TS E. Production of alcohol 2cd' (Table 3, entries 5 and 6) can be explained by the formation of oxonium intermediate $\mathbf{F},{ }^{16}$ which would be generated by an intramolecular cyclopropane ring-opening reaction as shown in Scheme 4. As chloride anion $\left(\mathrm{Cl}^{-}\right)$ is less reactive than bromide and iodide anions, ${ }^{17}$ the nucleophilic attack to intermediate $\mathbf{C}$ by the intramolecular carbonyl group or external water molecule occurred faster than chlorination.

The ring-opening reaction of 6-oxo analogue 5 under acidic conditions was also examined (Scheme 5). Treatment of $\mathbf{5}$ with $\mathrm{TMSCl}$ and $\mathrm{NaI}$ in aqueous acetonitrile smoothly afforded enone $\mathbf{6}$ in $83 \%$ yield even at $0{ }^{\circ} \mathrm{C}$. Product 6 was obtained as a 1:1 diastereomeric mixture but no formation of its regioisomeric product was observed. The nucleophile $\left(\mathrm{I}^{-}\right)$exclusively attacks at the less
Table 3 Reaction of 1c Having a Benzoyloxymethyl Substituent with Various $\mathrm{HX}^{\mathrm{a}}$

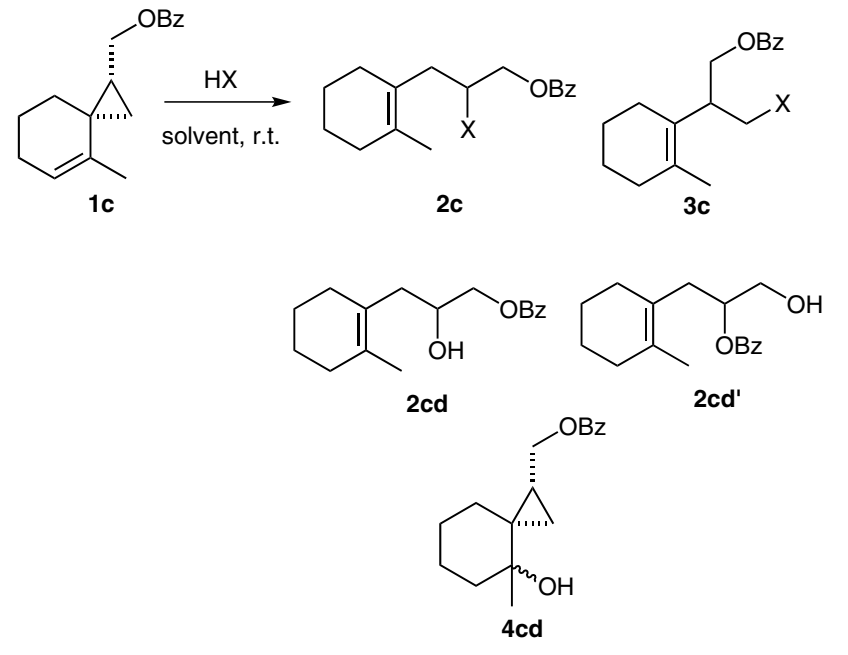

\begin{tabular}{lllll}
\hline Entry & $\mathrm{HX}$ & Solvent & Product ratio & Yield (\%) \\
\hline 1 & $\mathrm{HI}$ & $\mathrm{MeCN}$ & $\mathbf{2 c a} / \mathbf{3 c a} / \mathbf{4 c a}=0: 100: 0$ & 75 \\
2 & $\mathrm{HI}$ & $\mathrm{CH}_{2} \mathrm{Cl}_{2}$ & $\mathbf{2 c a} / \mathbf{3 c a} / \mathbf{4 c a}=9: 91: 0$ & 64 \\
3 & $\mathrm{HI}$ & toluene & $\mathbf{2 c a} / \mathbf{3 c a} / \mathbf{4 c a}=38: 62: 0$ & 69 \\
4 & $\mathrm{HBr}$ & $\mathrm{MeCN}$ & $\mathbf{2 c b} / \mathbf{3 c b} / \mathbf{4 c b}=23: 77: 0$ & 73 \\
5 & $\mathrm{HCl}$ & $\mathrm{MeCN}$ & $\mathbf{2 c / 3 c} / \mathbf{4 c}=27: 24: 49^{\mathrm{b}}$ & 67 \\
$6^{\mathrm{c}}$ & $\mathrm{HCl}$ & $\mathrm{MeCN}$ & $\mathbf{2 c / 3 c} / \mathbf{4 c}=72: 28: 0^{\mathrm{d}}$ & 82 \\
\hline
\end{tabular}

${ }^{a}$ Conditions: 1c $(0.1 \mathrm{mmol}), \mathrm{HX}$ (1.5 or 2.0 equiv), solvent $(0.2 \mathrm{M})$, r.t., $1-3 \mathrm{~h}$.

${ }^{\mathrm{b}}$ Compounds $2 \mathbf{c c}, \mathbf{2 c d}, \mathbf{2 c d}, \mathbf{3 c c}$, and $\mathbf{4 c d}$ were obtained in $8 \%, 8 \%$, $2 \%, 17 \%$, and $32 \%$, respectively.

${ }^{\mathrm{c}}$ The reaction was carried out at $80^{\circ} \mathrm{C}$.

${ }^{\mathrm{d}}$ Compounds $2 \mathrm{~cd}$ and $\mathbf{2 c d}$ ' were also obtained in $29 \%$ and $14 \%$ yield, respectively.

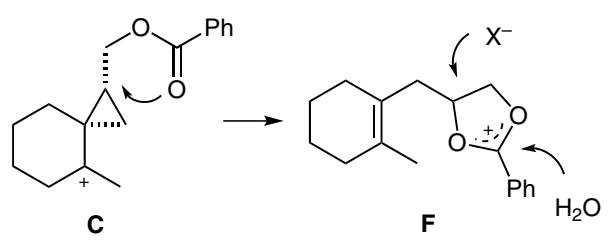

Scheme 4 Plausible mechanism for the formation of alcohols $2 \mathrm{~cd}$ and 2cd'

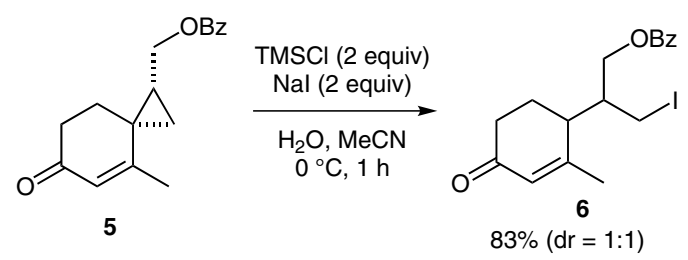

Scheme 5 Regioselective ring-opening reaction of 6-oxo-spiro[2.5] oct-4-ene $\mathbf{5}$ under acidic conditions 
substituted cyclopropane carbon atom of $\mathbf{5}$ as is the case of $1 \mathrm{c}$.

In conclusion, we have examined the ring-opening reaction of spirocyclic alkenylcyclopropanes under aqueous acidic conditions. It was elucidated that the regioselectivity in the cyclopropane cleavage was significantly dependent on the electronic nature of the substituent on the cyclopropane ring. The nature of the nucleophile also slightly influences the regioselectivity of the ring-opening reaction. We are currently engaging in the synthesis of new DNA-alkylating spirocyclic cyclopropane compounds. The new findings on the regioselectivity would help us in molecular designing.

\section{Typical Procedure for the Ring-Opening Reaction}

To a mixture of $1(0.10 \mathrm{mmol}), \mathrm{NaI}(0.20 \mathrm{mmol})$, and $\mathrm{H}_{2} \mathrm{O}(0.20$ $\mathrm{mmol})$ in $\mathrm{MeCN}(0.2 \mathrm{M})$ was added TMSCl $(0.20 \mathrm{mmol})$. Otherwise, to a mixture of $1(0.10 \mathrm{mmol})$ in $\mathrm{MeCN}$ was added aq concd $\mathrm{HCl}$ or $\mathrm{HBr}(0.20 \mathrm{mmol})$. After being stirred for $1 \mathrm{~h}$ at an appropriate temperature, the reaction mixture was quenched with sat. $\mathrm{Na}_{2} \mathrm{SO}_{3}$. The aqueous layer was extracted twice with EtOAc. The combined organic layers were washed with brine, dried over $\mathrm{Na}_{2} \mathrm{SO}_{4}$, and concentrated in vacuo. The residue was purified by silica gel chromatography (hexane-EtOAc) to afford desired $\mathbf{2}$ and $\mathbf{3}$.

\section{1-(2-Chloro-4-phenylbutyl)-2-methylcyclohexene (2ac)}

Colorless oil. ${ }^{1} \mathrm{H}$ NMR (400 MHz, $\mathrm{CDCl}_{3}$ ): $\delta=7.31-7.26(\mathrm{~m}, 2 \mathrm{H})$, 7.21-7.18 (m, 3 H), 4.01-3.94 (m, $1 \mathrm{H}), 2.93$ (ddd, $J=13.7,9.1,4.7$ $\mathrm{Hz}, 1 \mathrm{H}$ ), 2.73 (ddd, $J=16.6,9.3,7.5 \mathrm{~Hz}, 1 \mathrm{H}), 2.54$ (dd, $J=13.9$, $7.0 \mathrm{~Hz}, 1 \mathrm{H}), 2.44(\mathrm{dd}, J=13.9,7.3 \mathrm{~Hz}, 1 \mathrm{H}), 2.11-2.03(\mathrm{~m}, 1 \mathrm{H})$, $1.96-1.81(\mathrm{~m}, 5 \mathrm{H}), 1.60(\mathrm{~s}, 3 \mathrm{H}), 1.55-1.53(\mathrm{~m}, 4 \mathrm{H}) \mathrm{ppm} ;{ }^{13} \mathrm{C}$ NMR $\left(126 \mathrm{MHz}, \mathrm{CDCl}_{3}\right): \delta=141.2,129.7,128.5,128.4,126.3$, 126.0, 61.6, 42.7, 39.3, 32.8, 31.9, 29.8, 23.2, 23.1, 19.6 ppm. IR (neat): $2924,2831 \mathrm{~cm}^{-1}$. LRMS $\left(\mathrm{FAB}^{+}\right): m / z=262\left[\mathrm{M}^{+}\right]$. HRMS $\left(\mathrm{FAB}^{+}\right): m / z$ calcd for $\mathrm{C}_{17} \mathrm{H}_{24} \mathrm{Cl}\left[\mathrm{M}^{+}+\mathrm{H}\right]: 263.1561$; found: 263.1562 .

\section{1-[2-Benzoyloxy-1-(iodomethyl)ethyl]-2-methylcyclohexene} (3ca)

Colorless oil. ${ }^{1} \mathrm{H}$ NMR (500 MHz, $\left.\mathrm{CDCl}_{3}\right): \delta=8.01(\mathrm{~d}, J=8.3 \mathrm{~Hz}$, $2 \mathrm{H}), 7.57$ (t, $J=7.3 \mathrm{~Hz}, 1 \mathrm{H}), 7.46$ (dd, $J=8.3,7.3 \mathrm{~Hz}, 2 \mathrm{H}), 4.34$ $(\mathrm{dd}, J=11.0,7.1 \mathrm{~Hz}, 2 \mathrm{H}), 3.49-3.39(\mathrm{~m}, 1 \mathrm{H}), 3.39(\mathrm{dd}, J=9.5$, $6.3 \mathrm{~Hz}, 1 \mathrm{H}), 3.19(\mathrm{dd}, J=9.5,9.0 \mathrm{~Hz}, 1 \mathrm{H}), 2.05-1.86(\mathrm{~m}, 4 \mathrm{H}), 1.67$ $(\mathrm{s}, 3 \mathrm{H}), 1.63-1.56(\mathrm{~m}, 4 \mathrm{H}) \mathrm{ppm} .{ }^{13} \mathrm{C}$ NMR $\left(126 \mathrm{MHz}, \mathrm{CDCl}_{3}\right): \delta$ $=166.3,133.0,131.9,130.1,129.5,128.4,127.0,65.8,43.2,32.5$, 23.6, 23.0, 22.9, 19.4, 5.40 ppm. IR (neat): $2923,1721 \mathrm{~cm}^{-1}$. LRMS $\left(\mathrm{FAB}^{+}\right): m / z=385\left[\mathrm{M}^{+}+\mathrm{H}\right]$. Anal. Calcd for $\mathrm{C}_{17} \mathrm{H}_{21} \mathrm{IO}_{2}: \mathrm{C}, 53.14$; H, 5.51. Found: C, 53.34; H, 5.59.

\section{$\left(1 S^{*}, 3 R^{*}\right)$-1-Benzoyloxymethyl-4-hydroxy-4-methylspi-} ro[2.5]oct-4-ene (4cd)

Colorless oil. ${ }^{1} \mathrm{H}$ NMR $\left(400 \mathrm{MHz}, \mathrm{CDCl}_{3}\right): \delta$ (major isomer) $=8.06$ $(\mathrm{dd}, J=7.1,1.4 \mathrm{~Hz}, 2 \mathrm{H}), 7.56(\mathrm{tt}, J=7.3,1.4 \mathrm{~Hz}, 1 \mathrm{H}), 7.45(\mathrm{dd}, J$ $=7.3,7.1 \mathrm{~Hz}, 2 \mathrm{H}), 4.52(\mathrm{dd}, J=11.7,6.8 \mathrm{~Hz}, 1 \mathrm{H}), 4.21(\mathrm{dd}, J=$ $11.7,8.8 \mathrm{~Hz}, 1 \mathrm{H}), 1.76-1.37(\mathrm{~m}, 9 \mathrm{H}), 1.17(\mathrm{~s}, 3 \mathrm{H}), 0.85$ (dd, $J=$ 9.1, $4.9 \mathrm{~Hz}, 1 \mathrm{H}), 0.23(\mathrm{t}, J=4.9 \mathrm{~Hz}, 1 \mathrm{H}) \mathrm{ppm}$; isomeric ratio = 53:47. ${ }^{13} \mathrm{C}$ NMR $\left(126 \mathrm{MHz}, \mathrm{CDCl}_{3}\right): \delta$ (major isomer) $=166.7$, $132.8,130.5,129.5,128.4,71.2,65.5,39.8,31.2,28.5,25.1,24.7$, $23.4,17.3,13.7 \mathrm{ppm}$; isomeric ratio $=53: 47)$. IR (neat): 3497,2929 , 2860, 1715, $1699 \mathrm{~cm}^{-1}$. LRMS $\left(\mathrm{FAB}^{+}\right): m / z=257\left[\mathrm{M}^{+}-\mathrm{OH}\right]$. HRMS $\left(\mathrm{FAB}^{+}\right): m / z$ calcd for $\mathrm{C}_{17} \mathrm{H}_{21} \mathrm{O}_{2}\left[\mathrm{M}^{+}-\mathrm{OH}\right]: 257.1536$; found: 257.1541 .

\section{Acknowledgment}

This work was supported by Grants-in Aid for Young Scientists (KT) and JSPS Fellowship for Young Scientists (YN) from the Ministry of Education, Culture, Sports and Technology (MEXT), Japan, and the Astellas Foundation for Research on Metabolic Disorders.

Supporting Information for this article is available online at http://www.thieme-connect.com/ejournals/toc/synlett.

\section{References}

(1) (a) Danishefsky, S. Acc. Chem. Res. 1979, 12, 66. (b) Wong, H. N. C.; Hon, M. Y.; Tse, C. W.; Yip, Y. C.; Tanko, J.; Hudlicky, T. Chem. Rev. 1989, 89, 165. (c) Reissig, H.-U.; Zimmer, R. Chem. Rev. 2003, 103, 1151. (d) Yu, M.; Pagenkopf, B. L. Tetrahedron 2005, 61, 321. (e) Rubin, M.; Rubina, M.; Gevorgyan, V. Chem. Rev. 2007, 107, 3117. (f) Carson, C. A.; Kerr, M. A. Chem. Soc. Rev. 2009, 38, 3051. (g) Hudlicky, T.; Reed, J. W. Angew. Chem. Int. Ed. 2010, 49, 4864.

(2) (a) Donaldson, W. A. Tetrahedron 2001, 57, 8589. (b) Wolkenberg, S. E.; Boger, D. L. Chem. Rev. 2002, 102, 2477. (c) Wessjohann, L. A.; Brandt, W. Chem. Rev. 2003, 103, 1625. (d) Brackmann, F.; de Meijere, A. Chem. Rev. 2007, 107, 4493. (e) Chen, D. Y.-K.; Pouwer, R. H.; Richard, J.-A. Chem. Soc. Rev. 2012, 41, 4631.

(3) (a) Anchel, M.; Hervey, A.; Robbins, W. J. Proc. Natl. Acad. Sci. U.S.A. 1950, 36, 300. (b) McMorris, T. C.; Anchel, M. J. Am. Chem. Soc. 1963, 85, 831. (c) Niwa, H.; Ojika, M.; Wakamatsu, K.; Yamada, K.; Ohba, S.; Saito, Y.; Hirono, I.; Matsushita, M. Tetrahedron Lett. 1983, 24, 5371.

(4) (a) Ichimura, M.; Ogawa, T.; Takahashi, K.; Kobayashi, E.; Kawamoto, I.; Yasuzawa, T.; Takahashi, I.; Nakano, H. J. Antibiot. 1990, 43, 1037. (b) Ichimura, M.; Ogawa, T.; Takahashi, K.; Mihara, A.; Takahashi, I.; Nakano, H. Oncol. Res. 1993, 5, 165. (c) Yasuzawa, T.; Muroi, K.; Ichimura, M.; Takahashi, I.; Ogawa, T.; Takahashi, K.; Sano, H.; Saitoh, Y. Chem. Pharm. Bull. 1995, 43, 378.

(5) (a) McMorris, T. C.; Kelner, M. J.; Wang, W.; Moon, S.; Taetle, R. Chem. Res. Toxicol. 1990, 3, 574. (b) Dick, R. A.; Yu, X.; Kensler, T. W. Clin. Cancer Res. 2004, 10, 1492. (c) Gong, J.; Vaidyanathan, V. G.; Yu, X.; Kensler, T. W.; Peterson, L. A.; Sturla, S. J. J. Am. Chem. Soc. 2007, 129, 2101.

(6) Boger, D. L.; Johnson, D. S. Angew. Chem., Int. Ed. Engl. 1996, 35, 1438.

(7) Tanasova, M.; Sturla, S. J. Chem. Rev. 2012, 112, 3578.

(8) (a) MacMillan, K. S.; Boger, D. L. J. Med. Chem. 2009, 52, 5771. (b) Lajiness, J. P.; Robertson, W. M.; Dunwiddie, I.; Broward, M. A.; Vielhauer, G. A.; Weir, S. J.; Boger, D. L. J. Med. Chem. 2010, 53, 7731. (c) Lajiness, J. P.; Boger, D. L. J. Am. Chem. Soc. 2010, 132, 13936. (d) Tietze, L. F.; Hof, M.; Müller, M.; Krewer, B.; Schuberth, I. Angew. Chem. Int. Ed. 2010, 49, 7336. (e) Wirth, T.; Schmuck, K.; Tietze, L. F.; Sieber, S. A. Angew. Chem. Int. Ed. 2012, 51, 2874. (f) Stevenson, R. J.; Denny, W. A.; Tercel, M.; Pruijn, F. B.; Ashoorzadeh, A. J. Med. Chem. 2012, 55, 2780. (g) Wolfe, A. L.; Duncan, K. K.; Parelkar, N. K.; Weir, S. J.; Vielhauer, G. A.; Boger, D. L. J. Med. Chem. 2012, 55, 5878.

(9) (a) Cimino, P.; Improta, R.; Bifulco, G.; Riccio, R.; GomezPaloma, L.; Barone, V. J. Org. Chem. 2004, 69, 2816. (b) Cimino, P.; Gomez-Paloma, L.; Barone, V. J. Org. Chem. 2004, 69, 7414. 
(10) Takasu, K.; Nagamoto, Y.; Takemoto, Y. Chem. Eur. J. 2010, 16, 8427.

(11) (a) Wilhelm, D.; Bäckvall, J.-E.; Nordberg, R. E.; Norin, T. Organometallics 1985, 4, 1296. (b) Hanzawa, Y.; Harada, S.; Nishio, R.; Taguchi, T. Tetrahedron Lett. 1994, 35, 9421. (c) Larock, R. C.; Yum, E. K. Tetrahedron 1996, 52, 2743.

(d) Barrett, A. G. M.; Tam, W. J. Org. Chem. 1997, 62, 7673.

(12) (a) Srinivasulu, M.; Reddy, V. L. N.; Reddy, S. M.; Ravikanth, V.; Raju, T. V.; Ramakrishna, S.;

Venkateswarlu, Y. Helv. Chim. Acta 2005, 88, 2527.

(b) Lemechko, P.; Grau, F.; Antoniotti, S.; Duñach, E.
Tetrahedron Lett. 2007, 48, 5731. (c) Shi, W.-J.; Liu, Y.; Butti, P.; Togni, A. Adv. Synth. Catal. 2007, 349, 1619.

(13) Irifune, S.; Kibayashi, T.; Ishii, Y.; Ogawa, M. Synthesis 1988, 366.

(14) Sakaguchi, K.; Higashino, M.; Ohfune, Y. Tetrahedron 2003, 59, 6647.

(15) Zlokazov, M. V.; Veselovsky, V. V. Russ. Chem. Bull. 2000, 49, 154.

(16) Giner, J.-L.; Ferris, W. V. Jr.; Mullins, J. J. J. Org. Chem. 2002, 67, 4856.

(17) Stamatov, S. D.; Stawinski, J. Tetrahedron Lett. 2007, 48, 1887. 